DOI: $10.1590 / 2316-40183713$

\title{
O parricídio como espetáculo da violência: O dia em que matei meu pai
} Aileen El-Kadi

Mario Sabino, em O dia em que matei meu pai nos fala sobre os delírios, obsessões e medos de seu narcisista e ressentido personagem-narrador que relata em primeira pessoa a violenta relação que manteve com seu pai desde a infância até ser encerrado em uma instituição psiquiátrica depois de assassiná-lo. O protagonista é um sociopata incapaz de fugir de um limitado universo composto pelas fobias e fantasias estereotipadas de um jovem de classe média alta que, afetado por suas patologias psíquicas, percebe a sociedade como uma ameaça, uma força conspiradora que impossibilita o cumprimento de papéis e expectativas que sua classe social lhe impõe, ou, que ele imagina lhe são impostos. É justamente este componente da imaginação do protagonista que afetará o registro realista aproximando sua narração ao discurso do delírio.

O dia que matei meu pai era um dia claro, de uma claridade difusa, sem sombras, sem relevos. Ou talvez tenha sido cinzento, daquele cinza que tinge até as almas propensas a melancolia. (...) À primeira pancada, seu tronco projetou-se para a frente, como o de uma pessoa que se inclina para amarrar os sapatos. Dobrado sobre si próprio, recebeu o segundo golpe - a crisma que confirma o batismo. O filete de sangue correndo pelo canto da boca, a mão direita tremendo por segundos, antes de pousar inerte sobre o chão, o rosto com a expressão de espanto congelada. (Sabino, 2004, p. 9-10)

Sigmund Freud, em seu artigo "Formulations on the two principles of mental functioning" apresenta uma oposição entre o princípio do prazer e o da realidade, em que o primeiro deles rege os processos do inconsciente selecionando somente os estímulos que poderiam ser agradáveis e prazerosos ao indivíduo, sem levar em consideração a realidade objetiva. Isto é, a percepção do real ocorre pela projeção subjetiva formada pelos estímulos que produzem prazer. Oposto ao princípio do prazer, o princípio do real objetivo possibilita que a mente estabeleça uma concepção do mundo exterior com o fim de permitir alterações no mesmo. Aqui a realidade se forma pela apreciação "objetiva" das condições reais do universo exterior. Então, seguindo esta concepção dos dois tipos de princípios apresentados por Freud, a mimese das narrativas delirantes estaria estruturada 
seguindo o principio do prazer. Isto, porém, não significa que o âmbito do objetivo não esteja presente, está, o que não podemos é identificar um ponto de vista privilegiado que permita diferenciar estes dois âmbitos ou princípios estruturadores. $\mathrm{O}$ mundo criado por Sabino nesse romance pode ser considerado delirante, pois o leitor tem dificuldade para determinar quais elementos pertencem à realidade objetiva e quais são produto da imaginação do personagem. A falta de definição e vacilação do leitor em reconhecer as fronteiras entre o objetivo e o subjetivo é finalmente o que nos interessa, pois mesmo não sendo estritamente o resultado de uma poética do delírio, a hibridez e a ambiguidade que convergem no romance são suficientes para podermos questionar a estruturação formal do mundo da ficção em O dia em que matei meu pai.

A confissão do assassinato do pai pelo filho no começo do relato é um trecho central para entendermos a poética que propõe Mario Sabino no romance. Esta passagem oferece várias chaves de leitura. Em primeiro lugar, a confissão do crime pauta um shock inicial que inaugura uma segunda dimensão da realidade a qual opera sob um princípio de funcionamento que é a irrupção do delirante no universo da ficção. Este último ponto tem a ver com a gramática do texto que se baseia em dois modos de representação; um que oferece o tempo da rotina e está marcado por um estado de aparente calma, mas signado por uma permanente e progressiva agressão psicológica. Este modo permanecerá latente e subterrâneo permeando as duas lógicas presentes no texto, a social e a subjetiva, que é a do prazer/perversão. Esta ordem é interrompida por bruscos shocks, como o que abre o romance, que reposicionam a vítima (o filho) no papel de verdugo. A mobilidade destes papéis está conectada com um terceiro aspecto-chave no texto: a teatralidade por meio do espetacular.

Para compreender este caráter espetacular no texto devemos pôr atenção no modo em que se descreve o momento do crime no começo do romance. Estamos aqui frente a uma descrição oferecida não por um filho assassino, mas por um espectador e um esteta diante de um ato violento concebido como produto artístico e como show. O crime é descrito em termos pictóricos e teatrais, carente de toda carga emotiva que se esperaria diante de tal ação violenta. Por outro lado não se descreve somente um assassinato, mas a performance do personagem em seu ato de morrer. $\mathrm{O}$ narrador parece não ser agente do ato de violência, mas viver a experiência desde outra posição, uma posição que lhe dá prazer e é narrada desde o gozo estético originado pela agência e apreciação de uma violência descrita como espetáculo.

A ênfase dada a esses aspectos nos assinala que, além de estarmos frente a uma poética de natureza delirante, a realidade apresentada é 
baseada no excesso, uma "demasia" que produz uma imagem perversa da sociedade. A presença dessa estrutura dupla que perturba o regime de representação realista apresentando o delirante por meio do espetacular, do teatral, instala uma ordem que podemos chamar de hiper-real. A realidade que se recorta é manipulada de tal maneira que realça certo aspecto do objeto representado para que a percepção do receptor se concentre sobre um rasgo específico. Nesse caso, a ênfase é dada na seleção de características que definem a figura do pai como sádica, perversa e amoral, e ao mesmo tempo sobre a anomalia do papel paternal e seus efeitos negativos na formação da personalidade do filho.

Diante destas características poderíamos sugerir uma leitura deste romance como um texto que reflete sobre a crise da filiação na sociedade contemporânea desde o espaço da representação, estaríamos escolhendo um foco de análise que deixaria de lado as questões anteriores, as quais considero fundamentais na leitura do romance. Notemos que não há, na verdade, como na maioria das ficções que tratam da relação pai-filho, um desenvolvimento da tensão amor-ódio na relação dos dois personagens. Aqui o antagonista apresenta-se como uma espécie de doppelganger, um eu idealizado (e maldito) por parte do filho, uma figura que o protagonista tenta imitar, "jamais seria como meu pai" (Sabino, 2004, p. 164), mas que no processo de apropriação dessa persona acaba ridicularizando e, finalmente, destruindo. É por isso que através da dramatização do desejo de matar o pai e tomar seu lugar, ele acaba assumindo uma posição crítica e progressivamente mais complexa, cifrada através do índice de violência contida em sua confissão e no realce que dá a certos clichês de classe até convertê-los em hipérboles; esta estratégia faz com que o leitor experimente certa distância emocional com o narrado já que percebe a carga de artificiosidade que o narrador imprime na caracterização dos personagens e em suas interações. A voz narrativa converte os estereótipos em paródias de certo comportamento e valores sociais aos quais eles mesmos pertencem ${ }^{1}$.

Temos a impressão de que o narrador está o tempo todo "brincando" com a confiança que o leitor lhe tem: "o espetáculo que se desenrolava sobre a cama era horroroso: minha mãe, nua, cavalgava um pênis enorme. O pênis que eu sempre quisera ver e que sempre evitara olhar." (id., p. 19) para logo anunciar "(p)erdoe-me, mas nada do que contei ontem ocorreu. Quer dizer, apenas uma parte é verdade." (id., p. 21). Nas sucessivas

\footnotetext{
${ }^{1}$ No texto instala-se a lógica performática da imagem e do espetáculo como substitutos da sociedade. Para conseguir esse efeito o narrador anula a subjetividade dos personagens e modela suas condutas para que possam responder a certos estereótipos.
} 
menções feitas sobre a consciente manipulação do discurso para o seu receptor imaginário, o narrador nos assinala que detrás dessa aparente obviedade no uso de estereótipos existe uma voz irônica que chama a atenção sobre o caráter histriônico e, sobretudo de sobreatuação, da cultura contemporânea. Roger Caillois (1958) comenta que no jogo, os papéis e as regras criam narrativas, ficções, em que os jogadores tornam-se personagens dentro desse mundo paralelo, atuando como se fosse um universo real; o "como se" é chave na teoria do jogo de Caillois, pois aponta a criação de uma para-realidade que existe para os jogadores de maneira consciente, isto é, sendo parte do jogo os integrantes sabem que a ação de jogar/brincar consiste em uma imitação da realidade (a mimese) e esse conhecimento é implícito e tácito.

Esta para-realidade se instala no texto de Sabino como um sistema alternativo aos valores do pai (e, por contiguidade, à sociedade); e aqui há um ponto interessante, pois o narrador não optou por um sistema diferente ao identificado com o paterno, o mecanismo usado para criar uma diferença com a do pai é dada sob uma articulação semelhante a que comenta Caillois em relação ao jogo; o filho se apropria do sistema de valores do pai - apresentado como machista, materialista e classista - e o desloca a outra dimensão, a teatral, a da representação. Isto ocorre pela acentuação dos estereótipos e das fantasias de caráter sexual masculino presentes no imaginário social. Vejamos este exemplo:

Por meio do paladar, eu recobrava os sentidos em estado puro. Revivia a infância do homem, não como regresso, e sim como superação. (...) Naquela noite, recobrei minha potência com a mulher do senador. Trepamos quatro vezes durante a madrugada, e até hoje fico excitado ao lembrar dos gritos da desavergonhada. No dia seguinte, meu amigo me ligou. Pela sua insistência para que eu descrevesse os detalhes mais obscenos, deduzi que era voyeur. Eu estava certo, ele confessou sua perversão, compartilhada por sua mulher, e me propôs gravar em vídeo as minhas relações com a moça, sem o conhecimento dela. (Sabino, 2004, p. 98-9)

O excesso e o histriônico, como nesse exemplo, levam ao grotesco - e inclusive beiram o inverossímil. No desenrolar do romance temos a impressão de que os personagens estão interpretando papéis como se estivessem atuando em um happening e conscientemente tentando provocar efeitos nos leitores. Esta "reação" que se deseja provocar nos leva a pensar em certos gêneros cinematográficos tais como os de horror, melodramas, ou filmes pornográficos. Nestas variantes se usam elementos que, manipulados, sublinham certos aspectos na composição dos filmes para conseguir, por meio da saturação ou excesso, um determinado efeito (medo, 
emoção, excitação) no espectador. Isto é, o excesso em si é uma categoria que faz parte de um sistema estético que constitui a base do espetacular, mas é também por meio do uso destes mecanismos espetaculares que se consegue uma conexão emocional com o espectador, de quem se espera que reproduza mimeticamente a emoção ou resposta física do personagem destes filmes, isto é, que sinta terror, chore, ou se excite sexualmente, ou seja, que haja um envolvimento emocional.

Refiro-me a estes mecanismos, pois considero esta uma questão-chave para entendermos mais claramente o funcionamento da relação entre o narrador e o leitor ideal no texto. No romance de Sabino, a empatia que poderia estabelecer-se com o leitor se transforma em antipatia e o narrador assume um tom áspero para evitar o efeito de identificação do leitor com seu protagonista. A artificialidade das suas descrições é o que possibilita por parte do leitor já não a imediata identificação com as sensações implícitas pelo gênero, mas uma distância, uma distância estética digamos, que permite a conscientização da mecânica destas construções na ficção.

Curiosamente o uso da primeira pessoa nas ficções e não ficções tem como finalidade aproximar e envolver mais intimamente o leitor com a história narrada, porém a voz narrativa em $O$ dia em que matei meu pai impede esta aproximação e identificação entre o leitor e seus personagens. Com este gesto instaura-se outra dinâmica no texto, uma dinâmica que mantêm permanentemente certa estranheza entre o leitor/espectador e a ficção/espetáculo como parte de uma proposta literária que, ao quebrar o "encantamento" da ficção (Callois, 1958), obriga o leitor a uma mudança ou reposicionamento da sua perspectiva.

O autor não somente usa gêneros da cultura popular e do imaginário social para extrair dele os componentes que ele ressignifica em sua ficção, mas também faz coexistir tais componentes (sobretudo dos filmes ação, de terror, novelas, filmes pornográficos e o cinema gore) com elementos da cultura letrada, da psicanálise, das artes; "soube que minha analista escreveu que o meu narcisismo era tão monstruoso que, para me diferenciar dos mortais comuns, eu havia decidido imprimir na minha historia a marca do mito, transformando-me no próprio." (Sabino, 2004. 43)

$\mathrm{O}$ espaço de coexistência desses diversos elementos associados à cultura baixa e alta faz com que não exista uma hierarquia fixa e sim várias maneiras de organizar e interpretar essas vozes. Justamente a possibilidade de substituir uma lógica por outra é uma confirmação da mobilidade e artificialidade de seus componentes. Mais ainda, ao apresentar-nos um espaço descomedidamente artificial, o autor finca-pé na arbitrariedade da ordem e dos papéis sociais, e essa arbitrariedade é a que permite inaugurar uma lógica de caráter alternativo regido por outros princípios. 
O jogo de papéis estabelecido dentro da mimese lúdica funciona nos múltiplos níveis da ficção; por exemplo, o próprio protagonista, na relação ambivalente que estabelece com o pai, se identifica de maneira narcisista com o papel que representa e termina vítima do seu próprio personagem. Notemos que é a partir da posição - e do disfarce - de criminoso confesso trancado em um manicômio, de onde narra sua biografia. O limite entre a representação e a presença se dissolve, nós também como leitores (ou no papel de ouvintes) somos incorporados dentro de sua representação: "(v) ocê não conhecia esse meu lado misógino? Nem eu... Você também não esperava que saíssem da minha boca tantos clichês?" Na ficção o domínio do $e u$ biográfico é total, as outras vozes são anuladas e os personagens funcionam de acordo com a vontade do narrador-protagonista. Inclusive, ao incorporar uma narração em terceira pessoa nesse "romance dentro de um romance" - estratégia vastamente usada por escritores - o texto simplesmente reforça uma serie de analogias especulares entre os personagens de Futuro, o romance inconcluso escrito pelo protagonista, com os apresentados pelo narrador em primeira pessoa. Essa aparente diferença de voz da terceira pessoa de Futuro então deslocaria as fantasias do protagonista a outras subjetividades, sublinhando ainda mais o caráter excessivo destas construções estereotípicas. $\mathrm{O}$ tom e os temas tratados em Futuro são quase idênticos aos das outras partes ajudando ao estabelecimento de um universo coerente.

Em ambos os textos achamos personagens da classe média alta, que se sentem fracassados nas suas relações afetivas, no trabalho e apresentam patologias na dinâmica com os outros, como se a ênfase dada, sobretudo, às características e às atitudes que determinam os estereótipos da classe alta, servisse não somente para parodiar esse grupo social, mas para dramatizar ainda mais a difícil relação do protagonista com sua classe. Assim há, na sua sardônica rebeldia, no seu descompromiso político, e na sua falta de responsabilidade social e civil, um impulso contracultural, contestatário, de rejeição ao modelo paterno.

As sociopatologias dos personagens estão ligadas à posição moral ambígua deles e às referências à maldade que imprimem uns a outros. No caso do protagonista, a anomalia mental lhe serve de meio para se afastar do mundo real e diluir os limites entre o subjetivo e o objetivo habitando um estágio que lhe permite se aproximar de uma área escura de si mesmo e dos outros. A maldade e o ressentimento pareceriam guiar as relações entre pais e filhos, entre amantes e entre amigos. Esse mal geral que paira no romance pode ser explicado seguindo o estudo sobre a representação do mal e do diabólico de Jeffrey Burton Russel em Mephistopheles: The Devil in the Modern World, que afirma: 
Eu defino a maldade em duas categorias. A primeira é uma maldade passiva, é o sofrimento que um ser sensível sente. O sofrimento é o sentido consciente de medo, pavor, terror, agonia, depressão, ou o desespero que poderia acompanhar a dor ou a ameaça ou lembrança/memória de dor. A segunda é uma maldade ativa, a vontade de um ser sensível responsável de infringir sofrimento a outro ser. Tradicionalmente, a maldade foi dividida em três categorias: (1) maldade metafísica, a falta de perfeição inerente em qualquer mundo criado; (2) maldade natural, o sofrimento que provêm dos "atos da natureza" como o câncer e os furacões; (3) a maldade moral, a vontade deliberada de infringir sofrimento ${ }^{2}$. (Burton Russel, 1986, p. 17-8)

Talvez sejam as categorias 1 e 3 as que achamos combinadas no romance de Sabino. Efetivamente existe a presença de um mal na sociedade representada que perturba e condiciona as condutas dos personagens; trata-se dessa força negativa que o protagonista menciona e que pareceria desenvolver nele o transtorno psíquico pelo qual é levado a odiar e violentar outros personagens. A presença de um estado maléfico geral está ligada ao modo pelo qual o autor retrata a sociedade como um teatro das aparências, onde a perversão, a maldade e a violência estão ocultas em cada pessoa. A exterioridade de certa normalidade guarda em seu interior um mundo corrompido, amoral e decadente que evidencia a outra cara da urbe pós-moderna. Esta representação oferece, então, uma visão céptica e pessimista da sociedade contemporânea.

Na nossa atual "sociedade do espetáculo", como diria o teórico francês Guy Debord, se enfatiza o elemento performático e o excesso como modulações expressivas que afetam e determinam o modo de socializar e as produções culturais tanto nas artes como nos meios massivos de comunicação; Mario Sabino em O dia em que matei meu pai conjuga a poética realista com uma modulação, a do discurso delirante, para recriar por meio da mecânica da performance ou do universo lúdico, uma hiper-realidade. Este registro se afasta da representação conceitual, objetiva da realidade, propondo a percepção - e a experiência - do real desde outros sentidos, e lançando desde esta opção estética, uma crítica ao sistema, reforçada pela

${ }^{2}$ Tradução minha. No original: "I have (...) defined evil in two categories. The first is passive evil, the suffering that a sentient being feels. Suffering is the conscious sense of fear, dread, terror, agony, depression, or despair that may accompany pain or the threat or memory of pain. The second is active evil, the willingness of a responsible sentient being to inflict suffering upon a fellow sentient being. Traditionally, evil has been divided into three categories: (1) metaphysical evil, the lack of perfection inherent in any created world; (2) natural evil, the suffering that comes from "acts of nature" such as cancers and tornadoes; (3) moral evil, the deliberate willingness to inflict suffering." (Burton Russel, 1986, p. 17-8) 
distância permitida nesta variação da poética realista. Assim, o romance se apropria de uma gramática social composta por estereótipos que provêm da cultura de massas onde o valor do espetáculo e do simulacro é chave para representação da sociedade contemporânea.

Na mesma línea que Debord, o romance constitui-se como uma reflexão e revalorização crítica da sociedade, revelando a lógica que compõe noções relacionadas com aquilo que nos identifica e assinala perante os outros e as instituições; assim, gênero, sexo, classe, religião são exibidos como farsas, meras máscaras, que caem uma detrás da outra em um cenário de violências encobertas.

\section{Referencias bibliográficas}

BURTON RUSSEL, Jeffrey (1986). Mephistopheles: The Devil in the Modern World. Ithaca: Cornell University Press.

CALLOIS, Roger (1992). Les jeux et les hommes. Paris: Gallimard.

DEBORD, Guy (1992). La Société du spectacle. Paris: Les Éditions Gallimard.

FREUD, Sigmund (1911). Formulations on the two principles of mental functioning. Standard Edition. vol. 12.

SABINO, Mario (2004). O dia em que matei meu pai. Rio de Janeiro: Record.

Recebido em novembro de 2010.

Aprovado para publicação em fevereiro de 2011.

\section{resumolabstract}

\section{O parricídio como espetáculo da violência: $O$ dia em que matei meu pai}

\section{Aileen El-Kadi}

A voz narrativa em primeira pessoa no romance de Mario Sabino, $O$ dia em que matei meu pai, constrói um universo composto por duas coordenadas: uma segue a lógica subjetiva do prazer/perversão em que os personagens descritos pelo narrador evidenciam sociopatologias como resultado de um contexto regido pela violência psicológica e pela amoralidade, e onde a dinâmica erótica é sempre tanática; a outra tem como eixo o componente espetacular desde onde os personagens pareceriam representar papéis construídos em base a estereótipos que provêm da cultura de massas. $\mathrm{O}$ assassinato do pai pelo protagonista e o modo como confessa o crime no começo do romance conjugam os dois valores centrais que encontramos na proposta estética do autor: o valor da violência e do espetáculo para a representação da sociedade contemporânea.

Palavras-chave: parricídio, espetáculo, performance, maldade, hiper-realidade, Mario Sabino 


\section{The parricide as a spectacle of violence: O dia em que matei meu pai}

Aileen El-Kadi

The first person narrative voice in the novel by Mario Sabino, O dia em que matei meu pai, builds an universe composed of two coordinates, one follows the logic of subjective pleasure/perversion where the characters show social pathology described by the narrator as a result of a context governed by psychological violence and amorality, and where the dynamics is always erotic, the other component is spectacular as the axis from which the characters seem to represent roles built based on stereotypes that arise from mass culture. The father's murder by the protagonist and the way he confesses the crime at the beginning of the novel combine the two core values we find in the author's aesthetic proposed: the amount of violence and spectacle for the representation of contemporary society.

Key words: parricide, spectacle, performance, evil, hyperreality, Mario Sabino

Aileen El-Kadi - "O parricídio como espetáculo da violência: O dia em que matei meu pai". Estudos de Literatura Brasileira Contemporânea, n. 37. Brasília, janeiro-junho de 2011, p. 201-209. 